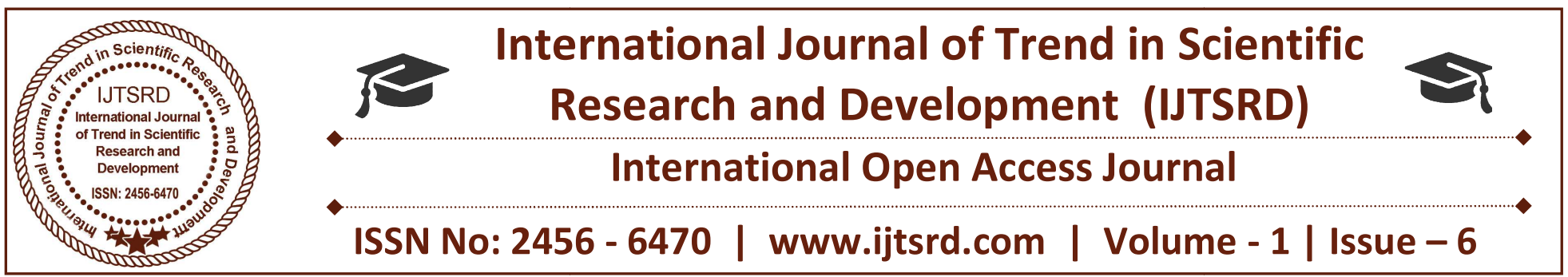

\title{
Crime and Its Dimension
}

\author{
Saurabh Bishwambhar \\ BBA-LLB (Hons.) $5^{\text {th }}$ year, ICFAI University, Dehradun
}

\section{INTRODUCTION}

The law of crime took birth along with our civilisation as soon as people grouped themselves into an organised society; the need for criminal law was immediately felt. The law reflects the public opinion and it is particularly true about the criminal law. Recent changes made in the form of amendments to Indian penal code are illustrative in these connections. The purpose of criminal law is to punish the criminals and to prevent recurrence of crime. Before the emergence of modern political state it was an individual's own responsibility to protect himself. That is why Sir Henry Mayne has called the ancient criminal law as law of wrongs. After political states came into being they shouldered the responsibility for maintenance of peace and order in the society.

The Aryans settled first in the country as wandering farmers. In course of time they made their own laws for their good government. The hindu law of crimes especially law of punishments is of immense importance. Of the leading codes of ancient india, the codes of manu is complete digest dealing with law, religion, custom and usages the prevalent; assault, battery, defamation, theft, robbery, gambling and cheating, trespass were the main offences of that time and the punishment prescribed for them was based on scientific principles and the highest prescribed punishment was the death sentence. Before punishing he offender, the social status, caste, etc of the accused plus factor leading to the commission of the crime were to kept in view. ${ }^{1}$ This shows that criminal

\footnotetext{
${ }^{1}$ At the instance of Warren Hastings Pandas of Varanasi prepared a code which is called as Jintoo Code. This contained provisions of criminal law in modified form.
}

jurisprudence of Manu is not free from bias. According to P.V. Kane ${ }^{2}$, "The mere ancient criminal law in India was very severe and drastic, but from the times of Yajnavalkya and Brahaspati the rigour of punishment was lessened and softened and fines came to be the ordinary punishment for many crimes". It thus becomes quite clear that there existed a well defined and systematic criminal law in ancient India. So people in those days also realised that systematic penal law was necessary for their existence in society.

The Muslims imposed criminal law or shara as they called it, on Hindus whom they had conquered. This was based on the Quran and believed to be of divine origin. Since laws of Quran and believed to be of divine origin. Since laws of Quran were inadequate to meet the entire requirement, so certain rules of conduct, called sunna were introduced. All offences for the punishment were classified under four broad principles.
1) Qisas (Retaliation)
2) Diyut (Blood Money)
3) Hadd (Fixed Penalities)
4) Ttazir (Discretionary Punishment)

Qisas applied specially to offences against a person, wilful killing and grave injury and the injured party had a right to inflict like injury on the offender. In certain cases where no retaliation was allowed, the injured party had a right to demand only blood money, known as Diyut. In the case of Hadd, the law

\footnotetext{
${ }^{2}$ History of Dharmashastra. Vol III, p.390.
} 
prescribed and fixed the penalities for certain offences, e.g. zina (illicit intercourse), drinking of wine, theft, highway robbers and accusing a married woman. In case of theft hands were cut off and for dacoity and robbery the maximum punishment was death.

Due to harshness and severity of punishments the proof of the crime alleged was made very essential. Where no punishment was prescribed it was at the discretion of the judge to give any sort of punishment. As such there was no uniform system of administration of criminal justice.

This type of Mohammedan criminal law suffered from many defects as many of its provisions were not in conformity with good government, natural justice and common sense. This is why the British introduced certain reforms from time to time. The first step was taken after the passing of the Regulating act,1773 which established one criminal court in each district which consisted of a kazi, a mufti and two Molvis. There was a court of criminal revision composed of a chief kazi, a chief Mufti and three Molvis. In 1793 European judges were appointed in these courts and four appellate courts were set up at Calcutta, Daca, Patna and Murshidabad. Then there was the Supreme criminal court at Calcutta known as Sadar Nizammat Adalat. The British now began to refer to the English law of crimes for their guidance but each presidency had a system of its own. As a result of contradicting statements and judgements on the same point of time were given by them. The rule precedence was unknown to them. In the mean time the charter act of 1833 introduced the system of single legislation for the whole of British India. In order to bring uniformity throughout India the First Law Commission appointed under the Chairmanship of Lord Macaulay prepared the draft Penal code which was revised twice by Subsequent Commissions. The final draft code was presented in the Legislative council in 1856 and then in 1857 and was finally passed and received the Governor general assent on October 6, 1860. In order to enable the people, judges and administrators etc. To know the provisions of the new penal code, its enforcement was deferred till January 1, 1862. Thus comprehensive criminal legislation for India was made available.

\section{CRIME; DEFINITION AND OVERVIEW}

Crime is a social phenomenon. It arises first when a state is organised people set up rules, the breaking of which is an act called crime. Law regulates the social interest, arbitrates conflicting claims and demands. The security of person and property is an essential function of the state and the same can be achieved through the instrumentality of criminal law. ${ }^{3}$

Many attempts have been made to define crime but it has not been possible to discover the most scientific definition workable in all case.

Some jurists have defined crime according to the interference by the state in criminal matters. That is why Austin while defining crime observed, "A Wrong which is pursued at the discretion of the injured party or his representatives is a civil injury, a wrong which is pursued by the sovereign or his subordinates is a crime". Goodhart simply called crime as any act which is penalised by the state.

Blackstone defined the term 'Crime' as "An act committed or omitted in violation of a public law forbidding or commanding it". His other definition is, "Crime is a violation of public rights and duties due to the whole community considered as community".

Stephen slightly altering it observed: "A Crime is a violation of right considered in reference to the evil tendency of such violation as regards the community at large". Neither of the above definitions presents a vivid picture before us.

Sir James Stephen in his books "History of Criminal Law" has observed, "Crime is an act which is both forbidden by law and revolting to the moral sentiments of the society".

More authoritative definition of crime has, however, been given by Prof. Kenny, the authority on English Criminal Law. According to him, "Crimes are wrongs whose sanction is punitive and is in no way remissible by any private person, but is remissible by the crown alone if remissible at all". This definition of Kenny is not of universal applicability and it does not apply to our own laws.

In fact "There is no satisfactory definition of crime which will embrace the many acts and omissions which are criminal and which will at the same exclude all those acts and omissions which are not. Ordinarily a crime is a wrong which affects the security or well being of public generally so that the public has an interest in its suppression. A crime is frequently a

\footnotetext{
${ }^{3}$ Mubarak Ali vs state. AIR 1957 SC 837
} 
moral wrong in that it amounts to conduct which is inimical to the general moral sense of the community." In accordance with the criminal legislation in force in the USSR(RUSSIA) a crime is a socially dangerous, unlawful, criminally punishable act which violates the Soviet Social or State system, the Socialist system of economy, Socialist Property, an Individual, or the political, labour, property and other rights of citizens or which violates Socialist Law and order 4

Whatever be the Definition of crime it is clear that it is a wrong committed by an individual in a society. Russel has perhaps rightly remarked that to define crime is a task which so far has not been satisfactorily accomplished by any writer.

That is why no definition of crime has been attempted in the Penal code which has used the term ofences in place of crime. Huda says that crime is an act that we consider worthy of serious condemnation. According to section 40, the word 'offences' denotes a thing made punishable by the code. Test of criminality prescribed under the code is its characteristic of punishment. Crime being a relative conception is an act prescribed by the state as a crime. Since the concept of crime changes from time to time, no fixed rules can ever be laid down for its determination. Whatever is the definition of crime but it certainly provides the base for proper study and understanding of the subject.

\section{DIMENSION OF CRIME}

The term Dimension signifies any matter in reference to its length, breadth, size and all aspect of determining value. Unlike Science principles crime could not be determine in aspects of values and a particular formulae because with the development of society and changing era the term crime shifts from one aspect to other and gets broader. Howsoever, to understand the pillars of crime we must identify and distinguish it from several other law aspects.

Firstly, we should make a distinction between crime and tort; According to Winfield, "Tortious Liability arises from the breach of duty primarily fixed by law, this duty is towards persons generally and its breach is

\footnotetext{
${ }^{4}$ Halsbury's Law of Engand, ${ }^{\text {th }}$ Edn., Vol.11, Para 1 and The Principles of Criminology (1982 Edn.) by Prof.G.Avanesov at pg.64.
}

redressible by an action for unliquidated damages". The definition of Tort clearly shows that an action for damages is the essential remedy. The case is otherwise in matter of crime. Although the difference is not fundamental and inherent but of degree only. In brief the differences are as under:

(i) Definition of Tort clearly exhibits that essential remedy for a tort is an action for damages. The object of criminal law is always punishment or to punish the offender and not to compensate for the injury sustained. In civil proceedings imprisonment awarded due to default in payments is coercive but in criminal trial the same is always punitive.

(ii) In tort action is always is brought by the injured party for compensation, while in crime the action is always brought by the state which represents the society and takes the responsibility to punish the offenders. In civil matters damages awarded go to the injured party but in a criminal action the offender is imprisoned and the fine imposed goes to the state Exchequer.

(iii) If the wrong is a civil injury the action is brought at the discretion of injured party but in crime the sanction is enforced at the discretion of state. It is so because tort does not threaten society as a whole but crime threatens the security and integrity of society.

In sum tort is civil injury and no great alarm is raised on its commitment. On the other hand crime is a serious threat to society and on its commitment a greater alarm is noticed in society. It is the combination of an act and an evil intent that distinguishes civil from criminal liability.

A distinction between Criminal Law and Morality is also to be understood in this regard where along the problem of the corelation of law and morality has always been at the centre of attention of the greatest thinkers of the society. A recognised morality is as necessary to society as say, a recognised government. The society may use the law to preserve morality in the same way as it uses it to safeguard anything else that is essential to existence. ${ }^{5}$ Every Jurist will agree that every society must accept certain moral principles

\footnotetext{
${ }^{5}$ The Enforcement of Morality by Patrick Devlin, (OUP-1965), p.11.
} 
for its survival. The standard of morality may differ from society to society. Certain morals are universal in character and common to all societies. It is the duty of the legislators to protect these morals by providing necessary safeguards. The law should in any case continue to support a minimum morality because roots of both systems are lying in the society itself.

So far criminal law is concerned its scope is narrower than that of morality as all crimes are immoral but vice versa is not true. In certain European countries, adultery and homosexuality are no crime but persons indulging in such acts will nevertheless be said to be practising immorality. What is moral or immoral, depends upon the standard of morality being practised in society. As society develops the concept of law and morality also goes for a change. No society could flourish without them and without either it may not exist at all. ${ }^{6}$ The courts in India should however be sensitive to the changing perspective and concept of morality to appreciate the effect of obscenity, moral turpitude on today's society in the light of its present standard and changing public opinion. While prosecuting and convicting a person summarily and imposing shall amount of fine, the future carrier of the convict must be kept in view. It should be treated as no conviction for any purposes. This is the need of the hour and the parliament should come forward to make a law on this point. The law and the courts must take cognizance of the changing moral standards. ${ }^{7}$

After distinction of crime from other matter of law part, we should now understand the dimension under the basis of its elements i.e. Fundamental Elements of crime.

There are four elements to constitute a crime;

\section{A human being}

\section{Guilty intention or mens rea on the part of such being}

\section{Actus reus, illegal act or omission}

\section{Injury to other human being}

A detailed analysis of each element is been denoted;

\footnotetext{
${ }^{6}$ Ibid.
}

${ }^{7}$ Pawan Kumar vs State, (1996) 4 SCC17: 1996 SCC (Cri) 583/
Human Being: The first element requires that the act must be committed by a human being. In ancient times when criminal law was largely dominated by idea of retribution, punishments were inflicted on animals also for the injury done by them. ${ }^{8}$ Now if an animal causes injury we hold not the animal but its owner liable for such injury. So old and primitive methods due to advancement of juridical ideas have completely disappeared. However no such practice was followed in india and with the development of notion of mens rea such trials and punishments were completely abandoned. So the first essential of crime is human being who (a) must be under legal obligation to act in a particular manner and (b) should be a fit subject for award of appropriate punishment. Section 11 of the I.P.C provides that the word 'person' includes a company, an association or a body of persons whether incorporated or not. The word person include artificial or Juridical person. "A Corporation according to Salmond is a group of series of persons which by legal fiction is regarded and treated as itself a person."

Corporations entail no criminal liability. It is due to the following reasons:

1. A Corporation has no physical body of its own and so it cannot be imprisoned.

2. Since a corporation has no mind of its own, it can never have a criminal intention. Moreover, a corporation acts only through its agent or servant and since there is nothing as vicarious liability under criminal law, no corporation can be held liable in the capacity of master. However, if individual members of a corporation entertain a criminal intent they are indictable.

3. The doctrine of ultra vires confines corporate activities within a defined limit. So a corporation can only be held liable for the act authorised by it. Since the corporation can never authorise the commission of a crime the question for its criminal liability does not arise.

In King vs Daily Mirror Newspaper ltd. ${ }^{9}$ it was held that a limited company cannot be committed for trial

\footnotetext{
${ }^{8}$ A pig was burnt in paris for having devoured a child, a horse was killed for having kicked a man. For details see Shamsul Huda- Law of crimes (1982 Reprint edn.), p15-16

9 Ibid.
} 
on an indictment and therefore, it cannot also be tried, it was pointed out in that case that in order that a person may be brought to trial, he must be committed for trial in the case.

The company could not be committed for trial because the interpretation acts, 1889 in England explained what was meant by the expression completed for trial and the provision was that the expression "committed for the trial" and the provision was that the expression" committed for trial shall mean committed to the person with a view to begin trade before a Judge or jury, the interpretation of "committed for trial" has not found place in the Indian law. There however have been cases where corporations have been convicted and fined for libel or nuisance and for breach of statutory duty imposed on it. In R vs Birmingham Rly.co the corporation was held liable for obstructing a highway whereby public nuisance was created.

In spite of well known decisions of English courts the law regarding criminal liability of corporations in England is not well defined and formulation of clear principles of criminal liability is urgently needed.

Criminal Liability of corporation is an imputed liability and not a vicarious liability. As the corporation itself cannot be executed or punished the liability is to be imputed to its high managerial agents who are responsible for the conduct of its policy and business. The fault or privity of the company is that the fault or privity of somebody who is not merely a servant or agent for whom the company is liable upon the footing of respondent superior, but somebody for whom the company is liable because his action is the very action of the company itself. ${ }^{10}$ For example section 17 of the prevention of Food Adulteration Act, 1954 provides that where an offence under the act has been committed by a company, every person who at the time the offence was committed was in charge of, and was responsible to the company for the conduct of the business of the company shall be deemed to be guilty of the offence and shall be liable to be punished.

Mens Rea The second important essential of crime is mens rea or evil intent. There can be no crime of any nature without an evil mind. Every crime requires a mental element. Even in strict or absolute liability some mental element is required. That is why mens

\footnotetext{
${ }^{10}$ Municipal Corporation vs J.B. Bottling Co., 1975 Cri LJ 1148
}

rea or actus non facit reum nisi mens sit rea is considered a fundamental principle of penal liability. The meaning of the term "actus non facit reum nisi mens sit rea" is that intent and act must both occur to constitute the crime. From this well known maxim follows the other proposition, actus me invito factus non set mens actus which means an act done by me against my will is not my act. It has however been a matter of great difficulty to arrive at the true meaning of mens rea.

In Sweat Parsley ${ }^{11}$ Lord Diplock said, "An act does not make a man guilty of a crime unless his mind be also guilty It is thus not the actus which is the reus but the man and his mind respectively.

The notion of mens rea as we understand today was however, fully established during the $14^{\text {th }}$ and $15^{\text {th }}$ centuries and by the end of the $17^{\text {th }}$ century it was universally settled law that mens rea (guilty intention) is an essential ingredienet of crime.no act of the person was punishable unless the same is done with evil intent.

\section{Mens rea in England:}

In $\mathrm{R}$ vs prince prince henry was tried for having unlawfully taken away an unmarried girl, below the age of 16 years, out of the lawful possession and against the will of her father, under the belief that he was eighteen. Jury found upon the evidence that before the defendant took her away the girl had told him that she was 18. It was held that the prisoner's belief about the age of the girl was no defence. It was argued that the statute did not insist on his knowledge of the accused that the girl was under 16 as necessary for conviction, the doctrine of mens rea should nevertheless be applied and conviction be set aside in the absence of criminal intention. Sixteen judges tried the case and all but one unanimously held the prince guilty. The real ground of conviction however was that the acused had committed an act which was forbidden by the statute and it was not only a legal wrong but also a moral wrong. Wright $J$ said in the case of Sherras vs. De Rutzen ${ }^{12}$ There is a presumption that mens rea, an evil intention, or a knowledge of the wrongfulness of the act, is an essential ingredient in every offence, but that presumption is liable to be displaced either by the

\footnotetext{
${ }^{11} 1970$ AC 132, 162: (1969) 1 AII ER 347

12 (1895) 1 QB 918. See also Sweet vs Parsley, (1969) 2 WLR 470: 1970 AC 132.
} 
words of the statute creating the offence or by the subject matter with which it deals, and both must be considered.

\section{Mens Rea in Indian Law:}

Sri J D Mayne, Rattan Lal and Gour have taken the view that doctrine of mens rea under the penal code is wholly out of place. Every offence is defined and definition states not only what the accused must have done, but also the state of his mind with regard to the act when he was doing it. Each definition of offence is complete in itself. The word mens rea has no where been used in the IPC but it has been applied in two different ways.

while defining offences words used indicate actual criminal intent required for the offence. The expression fraudulently, dishonestly, voluntarily and intentionally etc used in the definition indicate the criminal intent. No such words have however, been used in case of offences which cannot be committed by innocent persons. Such offences are Wwaging war against Government (Section 121), Sedition (Section124-A) and Counterfeiting of coins (Section 232) etc.

(ii) The IPC contains a separate chapter on general exceptions (Sections 76-106) which indicate the circumstances where absence of criminal intent may be presumed. This negative method of applying mens rea in the I.P.C has been found to be very useful.

The Doctrine of mens rea has been applied by courts in India and it is now firmly settled law that mens rea is an essential ingredient of offence. This point has come under judicial scrutiny on many occasions.

In Srinivasamal vs King Emperor ${ }^{13}$ a petrol dealer was acquitted on the ground that there was no guilty intention on the part of the accused as the act was committed without his knowledge. In State of Maharastra vs M.H. George- the accused was prosecuted by the state for bringing into India prohibited quantity of gold in violation of the statutory prohibitions imposed under section 8 of the Foreign Exchange Regulation Act, 1947 and notification issued thereunder. Holding the accused

\footnotetext{
${ }^{13}$ AIR 1947 PC 135
}

liable, the Supreme court held that unless the statute either clearly or by necessary implication rules out mens rea as a constituent part of a crime, an accused should not be found guilty unless he has got a guilty mind.

\section{Words denoting Mens rea in IPC;}

\section{Fraudulently and Dishonestly}

According to section 25 "A person is said to do a thing fraudulently if he does that thing to defraud but not otherwise." No definition of fraud has been given and there has been great reluctance among lawyers to define it. Fraud is the term which is been defined in Indian contract act, section 17 and it has there received a meaning much extensive for the purpose of the code. The expression defraud involves two element viz deceit and injury to the person deceived. According to Sir James Stephen ${ }^{14}$, a particular conclusive test as to the fraudulent character of a deception for criminal purpose in this: Did the author of the deceit derive any advantage from it which it could not have had if that truth had been known? If so it is hardly possible that advantage should not have had an equivalent in loss or risk of loss, to someone else, and if so, there was fraud.

According to section 24 "whoever does anything with the intention of causing wrongful gain to one person or wrongful loss to another, is said to do that thing dishonestly." According to section 23 "Wrongful gain is gain by unlawful means of property to which the person gaining is not legally entitled and wrongful loss is the loss by unlawful means of property to which the person losing it is legally entitled.

A person is said to gain wrongfully when he either retains or acquires wrongfully.

Similarly losing wrongfully means that the person is either wrongfully kept out of any property or is deprived of property. The gain or loss must be material and not remote.

Difference between Fraudulently and Dishonestly: The difference was pointed out in Emperor vs Abbas Ali ${ }^{15}$. In this case the accused had forged a certificate

\footnotetext{
${ }^{14}$ History of Criminal Law.

1525 CAL 512, See also L.M. Sen v. Queen, 22 Cal 313 where court said that fraudulently must mean something different from dishonestly
} 
in order to qualify himself for the examination of engine driver. It was observed that fraudulently and dishonestly does not cover the same ground and that intention to defraud does not necessarily involve deprivation of property. Shamshul Huda (16) had differentiated them as such"

1. Fraud involves deception necessarily while dishonestly does not.

2. Dishonestly necessarily involves the idea of injury to property as well as injury of every other kind i.e. injury to body, mind or reputation.

3. A dishonest intention is intention to cause loss of specified property belonging to a particular person. Fraudulently on the other hand may refer to injury in respect of unspecified property, to unknown and unascertained persons.

4. Deception is essential for fraud but not for dishonesty and wrongful gain or wrongful loss of property is necessary for dishonesty but not for fraud. An act may be dishonest an yet not fraudulent.

\section{VOLUNTARILY}

According to section 39, "A person is said to cause an effect voluntarily when he causes it by means which, at the time of employing those means, he knew or had reason to believe to be likely to cause it". In ordinary sense the word 'voluntarily' means an act done without influence or compulsion. The section therefore, emphasises the well known rule of law that a man is presumed to intend the probable consequences of his acts. The word as used in section 39 takes into account not only intention but also knowledge and reasonable grounds of belief. Section 39 contains an illustration. A sets fire by night to an inhabitated house in a large town for the purpose of facilitating robbery and thus causes the death of a person. Here, A may not have intended to cause death, and may even be sorry that death has been caused" yet he has caused death voluntarily as he knows that death was probable consequence. A must have a reason to believe that by setting fire at night to a house in a crowded town, he is likely to cause the death of the person who may be inside the house.

Voluntarily cauing an effect embraces, (i) with intention to cause the effect, (ii) with the knowledge of likelihood of causing the effect, and (iii) having reasons to believe that the effect is likely to be caused. If the doer of an act knows or believes that dangerous result will emerge from his act, he will be said to have acted with the most direct intention to hurt. 'Intention', 'Knowledge' and 'reason to believe' are the words of most importance in this respect. 'Intention' means to have in mind a fixed purpose to reach a desired objectives, so it indicates that a man is consciously shaping his conduct so as to bring about a certain event. In simple words Intention is the purpose or design with which an act is done. 'intention' differs from motive and law only take notice of intention only. If intention is criminal, law provides punishment even though the act is done with the best of the motive.

In Emperor vs Raghu Nath Rai, ${ }^{16}$ a hindu took away a calf from a Mohammedan's house without his knowledge and consent in order to save it from slaughter. The accused was held guilty of theft and rioting although he acted with the best of motive to save the life of the sacred cow.Motive is relevant only in ascertaining the guilt of the accused as it is directed to the ultimate end, good or bad, which a person hopes to secure. As such motive, object or design of a person should never be confused with his intention.

Motive is something which prompts a man to form an intention and knowledge is an awareness of the consequences of the act. In many cases Intention and knowledge merge into each other and mean the same thing more or less and intention can be presumed from knowledge. The demarcating line between knowledge and intention is no doubt thin but it is not difficult to perceive that they connote different things.

Knowledge means having mental cognition of a thing or it is the awareness or expectations of the consequences of the act. The main difference between knowledge and intention is that in the former the consequences is not desired whereas in the latter it is desired.

There are few more words denoting mens rea but these have not been defined under IPC but have simply been used in different sections. These words are corruptly, malignantly, wantonly, rashly and negligently. The word corruptly has been used in section 196,198,200,219,220 and it is used to denote impropriety brought about by bribery or undue

${ }^{16}$ (1892) 15 AII 22 
influence. In Bibhuranjan Gupta vs King ${ }^{17}$ the Calcutta high court said the word "corruptly" was not synonymous with dishonestly or fraudulently but was much wider. It even included conduct which was neither fraudulent nor dishonest if it was otherwise blameworthy or improper.

\section{ACTUS REUS (ACT OR OMISSION)}

The third essential element of a crime is actus reus. In other words some overt act or illegal omission must take place in pursuance of the guilty intention. Prof Kenny ${ }^{18}$ has defined the term thus, "Such result of Human conduct as the law seeks to pevent". He was the first writer to use the term 'actus reus'and Russel called it physical event. The actus reus is constituted by the event and not by the activity which caused the event. A deed may consist of harm and destruction of property and even of life, but it is not a crime unless the circumstances are such that is legally prohibited. Accordingly no crime is committed by a duly appointed executioner who hangs to death a criminal because in spite of his full intention to kill, his act was commanded by he law. Similarly no crime is committed and no criminal liability arises when hurt is inflicted by a properly skilled person in the course of surgical or dental operation upon a patient. It would, however, be unlawful (or actus reus) if the accused is put to death by an unauthorised person or even by the lawfully appointed executioner if the method of taking the accused's life was unlawful ${ }^{19}$. It is one of the essential principle of criminal jurisprudence that a crime is not committed if the mind of a person doing the act in question is innocent.

\section{INJURY}

The fourth requirement in crime, the aspectual dimension which is been caused to another person or to society at large.(Delhi rape case) the injury should be illegally caused to any person in body, mind, reputation or property as according to section 44 the word "injury" denotes any harm whatever illegally caused to any person in body, mind, reputation or property. The word injury is of wide connotation and includes all injuries caused by tortious act. Three sections in the code specifically deals with threat of injury, i.e. section 189- threat of injury to public servant, section 190- threat of injury to induce person to refrain from applying for protection to public servant and section 385- putting a person in fear of injury in order to commit extortion. A false charge laid before the public and never intended to be prosecuted in court may obviously subject the accused party to very substantial injury. So also unlawful detention of a cart for realising illegal toll is an injury. Social boycott of a person in order to compel him to cooperate with his fellow workmen in collective bargain for securing better terms, does not amount to an injury within section 44 . Threat of a decree that could not be executed by any competent court amounts to harm or injury within meaning of section 44.

\section{CONCLUSION}

The above four element that go to constitute a crime. It will not be out of place to say something here about good faith which plays a vital role in the law of crimes. ${ }^{20}$ Words "due care" and "attention" used in section 52 are of importance and on proper analysis of definition it is derived that a thing shall be deemed to be done in good faith where in fact it is done with the care and attention. In this paper I have tried to cover the basic elements of crime which constitutes as its dimension. The four elements been discuss is the basic pillar of the crime. Its constituents and related provisions are been mentioned where in the end conclusion as per the definition of Rousseau "Crime is any wrong which is committed by any person against any human being."

\footnotetext{
${ }^{17}$ ILR (1949) 2 CAL440 approved in AIR 1966 SC 523

${ }^{18}$ Outlines of Criminal law, $19^{\text {th }}$ Edn, p-17

${ }^{19}$ Kenny's Outline of Criminal Law, $19^{\mathrm{TH}}$ Edn, p. 18
}

${ }^{20}$ Kartar Singh vs State, (1994) 3 SCC 569: 1994 SCC (Cri)889 